\title{
Perception of Domestic Garuda Frequent Flyer Cardholders Toward Customer Relationship Management at PT. Garuda Indonesia Denpasar
}

\author{
Putu Ayu Aryasih ${ }^{1}$, Made Darmiati ${ }^{2}$, M. Tanggap Sasmita ${ }^{3}$ \\ \{aryasih.ayu@gmail.com ${ }^{1}$ \} \\ Sekolah Tinggi Pariwisata Nusa Dua Bali, Jl. Dharmawangsa, Benoa, Kec. Kuta Sel., Kabupaten \\ Badung, Bali, Indonesia ${ }^{123}$
}

\begin{abstract}
Customer Relationship Management is a management strategy approach in an effort to create, develop, and realize mutually beneficial relationships with customers in the long term, especially to potential customers, in an effort to maximize customer value and customer profitability. Customer Relationship Management concentrates on three main things: Acquire, Enhance, and Retain. This study discusses Garuda's Frequent Flyer of cardholders toward customer relationship management at PT. Garuda Indonesia Denpasar. Respondents are the population in GFF registered at the company, which are 100 respondents. Using likert scale, each variable is performed and then the average score for each question will be calculated.
\end{abstract}

Keywords: customer relationship management, customer perception, likert scale

\section{Introduction}

PT. Garuda Indonesia implements a marketing system known as Customer Relationship Management (CRM), as one of the strategies to compete globally, to build customer loyalty and retain customers.

CRM is a system implemented by the company with an orientation to improve service quality and maintain customer relationships. CRM implementation allows customer satisfaction because it establishes, maintains, and strengthens the relationship between the organization and customers, by looking at customers like partners [1]. Another understanding according to James G. Barnes customer Relationship Management relates to the mechanism of building a relationship, including data acquisition, analysis, and simplification of business processes [2]. Whereas according to Buttle, Francis customer Relationship Management is a management strategy approach in an effort to create, develop, and realize mutually beneficial relationships with customers in the long term, especially to potential customers, in an effort to maximize customer value and customer profitability [3]. According to Kalakota \& Robinson Customer Relationship Management concentrates on three main things: Acquire, Enhance, and Retain [4]. Acquire is a way for a company to gain new customers by promoting innovative products and excellence in services that differentiate them from other companies. New customers are obtained by providing easy access to information, new innovations, and attractive services. Retain is the company's effort to retain customers and focus on service adaptation, where the company is expected to fulfill what customers need and provide services 
that are one stop service for all matters related to customers. While Enhance is a company process in strengthening relationships with customers. This stage is an effort to get customer loyalty by listening to customers and trying to meet customer desires.

To maintain customer loyalty, PT. Garuda Indonesia is implementing the Frequent Flyer program. This program is a customer appreciation service held by many leading companies where customers who are program participants will have the opportunity to collect milliage according to the distance of the flight, which can then be exchanged for free flights. Frequent flyer programs generally provide a variety of extra services according to the level of customer loyalty. Garuda Indonesia holds a frequent flyer program known as Garuda Frequent Flyer (GFF).

GFF (Garuda Frequent Flyer) is a form of appreciation for Garuda Indonesia loyal customers. The GFF card has 4 different level classifications; Blue, Silver, Gold and Platinum.

Table 1.1 Number of Garuda Frequent Flyer Card Members. 2013-2016

\begin{tabular}{|c|c|c|c|}
\hline No & Year & Number of Members (People) & Percentage (\%) \\
\hline 1 & 2013 & 48.201 & - \\
\hline 2 & 2014 & 53.909 & $11,84 \%$ \\
\hline 3 & 2015 & 68.982 & $27,96 \%$ \\
\hline 4 & 2016 & 87.452 & $26,87 \%$ \\
\hline
\end{tabular}

Source: PT. Garuda Indonesia Branch Denpasar, 2017

Based on Table 1.1, it can be seen that the number of GFF (Garuda Frequent Flyer) members increases every year, the number of members is taken from GFF membership registered as a member at Garuda Indonesia Denpasar. Based on this, the writer wants to know the perception of domestic customers of Garuda Frequent Flyer (GFF) cardholders on Customer Relationship Management (CRM) at PT. Garuda Indonesia Denpasar.

\section{Method}

The research method is an attempt to find develop and examine the truth of a knowledge. The method is in addition used as a tool to draw conclusions, explain and analyze problems, but also used to solve problems. The theories used to solve the problem are as follows: structural functional theory and value theory [5]. The methods used for data collection include observation, interview, bibliography, documentation. Data analysis is done through qualitative descriptive technique.

\section{Result and Discussion}

This sub will discuss the perception of domestic customers of Garuda Frequent Flyer (GFF) card holders on Customer Relationship Management (CRM) at PT. Garuda Indonesia 
Denpasar. This data was obtained through a questionnaire distributed to Garuda Indonesia airline customers, especially GFF card holders (Garuda Frequent Flyer). The population in this research were all domestic members of GFF registered at PT. Garuda Indonesia (Persero) Branch Office, Denpasar as many as 100 respondents. Each respondent has different characteristics when viewed from the demographic structure, the characteristics studied include age, gender, level of education, type of work and frequency of use of GFF services.

Frequency distribution is obtained from the respondent's score, while the interpretation of item scores in the research variables is in table 2.1. Each variable is measured by 5 (five) questions using a scale of $1-5$, then with this scale the calculation of the score is performed and then the average score for each question will be calculated.

Table 2.1 Determination of Research Criteria

\begin{tabular}{|c|c|}
\hline Value Range & Category \\
\hline $1,00-1,80$ & Very Poor \\
\hline $1,81-2,60$ & Poor \\
\hline $2,61-3,40$ & Enough \\
\hline $3,41-4,20$ & Good \\
\hline $4,21-5,00$ & Very Good \\
\hline
\end{tabular}

1) Acquire

Acquire in the context of Customer Relationship Management (CRM) is the way a company obtains new customers by promoting innovative products and excellence in services that differentiate them from other companies.

The results of research on consumer perceptions of the Acquire variable can be seen in table 2.2 as follows:

Table 2.2 Distribution of Respondent Answers on Variable Acquire

\begin{tabular}{|c|c|c|c|c|c|c|c|c|c|c|c|c|c|}
\hline \multirow{3}{*}{$\begin{array}{l}\text { Number } \\
\text { of Items }\end{array}$} & \multicolumn{10}{|c|}{ Scale } & \multirow{2}{*}{\multicolumn{2}{|c|}{ Total }} & \multirow{3}{*}{ Mean } \\
\hline & \multicolumn{2}{|c|}{5} & \multicolumn{2}{|c|}{4} & \multicolumn{2}{|c|}{3} & \multicolumn{2}{|c|}{2} & \multicolumn{2}{|c|}{1} & & & \\
\hline & Score & Freq & Score & Freq & Score & Freq & Score & Freq & Score & Freq & Score & Freq & \\
\hline $\mathrm{X} 1$ & 17 & 85 & 55 & 220 & 19 & 57 & 9 & 18 & 0 & 0 & 100 & 380 & 3.80 \\
\hline $\mathrm{X} 2$ & 13 & 65 & 58 & 232 & 25 & 75 & 3 & 6 & 1 & 1 & 100 & 379 & 3.79 \\
\hline X3 & 5 & 25 & 59 & 236 & 29 & 87 & 7 & 14 & 0 & 0 & 100 & 362 & 3.62 \\
\hline $\mathrm{X} 4$ & 10 & 50 & 57 & 228 & 25 & 75 & 8 & 16 & 0 & 0 & 100 & 369 & 3.69 \\
\hline X5 & 17 & 85 & 46 & 184 & 30 & 90 & 7 & 14 & 0 & 0 & 100 & 373 & 3.73 \\
\hline Total & 62 & 310 & 275 & 1100 & 128 & 384 & 34 & 68 & 1 & 1 & 500 & 1863 & 3.72 \\
\hline
\end{tabular}

Source: Research results, 2017

Based on Table 2.2, it can be seen that the respondent's perception of the Acquire variable is in the Good category. This is indicated by the result of Acquire variables is 3.72. 


\section{2) Retain}

Retain is a company effort to maintain customers and focus on service adaptation, where the company is expected to be able to fulfill what customers need and provide services that are one stop service for all matters related to customers.

The results of research on consumer perceptions of Retain variables can be seen in table 2.3 as follows:

Table 2.3. Distribution of Respondent Answers on Variable Retain

\begin{tabular}{|c|c|c|c|c|c|c|c|c|c|c|c|c|c|}
\hline \multirow{3}{*}{$\begin{array}{l}\text { Number } \\
\text { of Items }\end{array}$} & \multicolumn{10}{|c|}{ Scale } & \multirow{2}{*}{\multicolumn{2}{|c|}{ Total }} & \multirow{3}{*}{ Mean } \\
\hline & \multicolumn{2}{|c|}{5} & \multicolumn{2}{|c|}{4} & \multicolumn{2}{|c|}{3} & \multicolumn{2}{|c|}{2} & \multicolumn{2}{|l|}{1} & & & \\
\hline & Score & Freq & Score & Freq & Score & Freq & Score & Freq & Score & Freq & Score & Freq & \\
\hline X6 & 26 & $\begin{array}{c}13 \\
0 \\
\end{array}$ & 57 & 228 & 14 & 42 & 3 & 6 & 0 & 0 & 100 & 406 & 4.06 \\
\hline $\mathrm{X} 7$ & 23 & $\begin{array}{c}11 \\
5\end{array}$ & 61 & 244 & 12 & 36 & 3 & 6 & 1 & 1 & 100 & 402 & 4.02 \\
\hline $\mathrm{X} 8$ & 18 & 90 & 55 & 220 & 18 & 54 & 9 & 18 & 0 & 0 & 100 & 382 & 3.82 \\
\hline X9 & 19 & 95 & 56 & 224 & 23 & 69 & 2 & 4 & 0 & 0 & 100 & 392 & 3.92 \\
\hline $\mathrm{X} 10$ & 18 & 90 & 46 & 184 & 29 & 87 & 7 & 14 & 0 & 0 & 100 & 375 & 3.75 \\
\hline Total & 104 & $\begin{array}{c}52 \\
0\end{array}$ & 275 & 1100 & 96 & 288 & 24 & 48 & 1 & 1 & 500 & 1957 & 3.91 \\
\hline
\end{tabular}

Source: Research results, 2017

Based on Table 2.3, it can be seen that respondents' perceptions of Retain variables are in the Good category. This is indicated by the result of Retain variables is 3.91.

3) Enhance

Enhance is a company process in strengthening customer relationships. The company creates relationships with the way companies listen to complaints and improve services.

The results of research on consumer perceptions of Enhance variables can be seen in table 2.4 as follows:

Table 2.4. Distribution of Respondent Answers on Variable Enhance

\begin{tabular}{|c|c|c|c|c|c|c|c|c|c|c|c|c|c|}
\hline \multirow{3}{*}{$\begin{array}{l}\text { Num } \\
\text { ber of } \\
\text { Items }\end{array}$} & \multicolumn{10}{|c|}{ Scale } & \multicolumn{2}{|c|}{ Total } & \multirow[t]{2}{*}{ Mean } \\
\hline & \multicolumn{2}{|c|}{5} & \multicolumn{2}{|c|}{4} & \multicolumn{2}{|c|}{3} & \multicolumn{2}{|c|}{2} & \multicolumn{2}{|c|}{1} & & & \\
\hline & Score & $\begin{array}{c}\text { Fre } \\
\mathrm{q}\end{array}$ & Score & Freq & Score & Freq & Score & Freq & Score & Freq & Score & Freq & \\
\hline X11 & 25 & 125 & 55 & 220 & 12 & 36 & 7 & 14 & 1 & 1 & 100 & 396 & 3.96 \\
\hline $\mathrm{X} 12$ & 24 & 120 & 50 & 200 & 17 & 51 & 8 & 16 & 1 & 1 & 100 & 388 & 3.88 \\
\hline X13 & 16 & 80 & 53 & 212 & 19 & 57 & 12 & 24 & 0 & 0 & 100 & 373 & 3.73 \\
\hline X14 & 19 & 95 & 46 & 184 & 20 & 60 & 15 & 30 & 0 & 0 & 100 & 369 & 3.69 \\
\hline $\mathrm{X} 15$ & 16 & 80 & 35 & 140 & 37 & 111 & 12 & 24 & 0 & 0 & 100 & 355 & 3.55 \\
\hline $\mathrm{X} 16$ & 20 & 100 & 35 & 140 & 34 & 102 & 11 & 22 & 0 & 0 & 100 & 364 & 3.64 \\
\hline Total & 100 & 500 & 239 & 956 & 105 & 315 & 54 & $\begin{array}{c}10 \\
8\end{array}$ & 2 & 2 & 500 & 1881 & 3.76 \\
\hline
\end{tabular}


Source: Research results, 2017

Based on Table 2.4 it can be seen that respondents' perception of the Enhance variable is in the Good category. This is indicated by the result of Enhance variables is 3.76.

\section{Conclusions}

Based on the results of the discussion it can be concluded that the Garuda Frequent perception of domestic Flyer cardholders toward Customer Relationship Management at PT. Garuda Indonesia Denpasar is Good with an average value of the three variables (Acquire, Retain, Enhance) which is 3.79 .

The Acquire CRM element has the lowest average value, this means that the effectiveness of CRM by PT. Garuda Indonesia Denpasar has not provided the maximum contribution. Some things can be done in a more innovative way, so customers are attracted to the product being promoted. For example, by promoting more products directly through customer service or ticketing staff, through brochures stored in each ticket sales counter. Furthermore, to maintain elements of CRM Retain, things that can be done for example periodically communicate the purpose to know customer desires, and improve promos for customers who are already registered, the goal is that customers do not switch. Then finally increase the element of CRM Enhance, things that can be done such as more often communicating with customers via e-mail or telephone to ask things that are lacking in the product, and identify things that are liked or disliked by customers.

\section{References}

[1] L. I. Darsono, "Hubungan Perceived Service Quality dan Loyalitas: Peran Trust dan Satisfaction Sebagai Mediator,” J. Bisnis Perspekt., vol. 2, pp. 43-57, 2010.

[2] J. G. Barnes, Secret of Customer Relationship Management. Yogyakarta: Andi, 2003.

[3] F. Buttle, CRM Manajemen Hubungan Pelanggan Concept and Tools. Malang: Bayumedia Publishing, 2007.

[4] R. Kalakota and M. Robinson, e-Business 2.0 Roadmap for Success. Canada: Addison-Wesley, 2001.

[5] F. Soares and I. K. Sudarsana, "Religious Harmony Among Senior High School Students Multicultural Education Case Study in the Cova-Lima District of East Timor," Vidyottama Sanatana Int. J. Hindu Sci. Relig. Stud., vol. 2, no. 1, p. 154, May 2018. 